$A D D I N$, Volume 11, Number 1, February 2017

\title{
MOVING IJTIHAD AND TAJDID ON AMAL USAHA MUHAMMADIYAH (AUM) IN BUILDING THE CIVILIZATION OF ISLAMIC ECONOMY
}

\section{Dharma Setyawan}

IAIN Metro, Lampung, Indonesia

dharmasetyawan@rocketmail.com

\section{Abstract}

Muhammadiyah declares that the gate of ijtihad (reasoning) and tajdid (modernization) were being yet continued. Ijtihad was the base core to establish the main character of Mubammadiyah as a Modern Islamic Modernization Movement. Then, the establishment on tajdid (modernization) grows as a motor to improve the system of its movement on finding the solution to ideology problem, politic, business, social, cultural, and defence. Muhammadiyah, which the first time moved on social-religious track, was still upbringing to comprehend and rolling in the progressivity of Moslem society as in the case Indonesia. By ijtihad (reasoning) and tajdid (modernization), the role-model of Muhammadiyah as a social-religious movement grows its root on business practice. The Council of Business and Enterpreneurship (MEK) of Mubammadiyah schedules on developing the House for Charity of Mubammadiyah (AUM). Dawam Rahardjo (2000) confirms, a large number of member and institution will represent as a comparative advantage capital resources to the movement of Muhammadiyah. Those resources orchestrate Mubammadiyah as an 
organization which is not only moves on social-education-and-religious practices, but as well in business and finance. At least, there are two reasons why Muhammadiyah rolls in business practice. Firstly, Muhammadiyah perform to roll in this business merit by the image of intechangible advantages to other charities: as well as schools, hospitals or religious calls. Secondly, Mubammadiyah sustains a potential power to organize those. That is supported by the fact that there are many beureucrates possess in higher structural of Mubammadiyah, the large number of buman resources out-put by Muhammadiyah schools, the enterpreneurs possessions, and large number of its members. This paper researches the Mubammadiyab-Nomic, the contribution of ijtibad and tajdid on Charitable Enterprises of Mubammadiyah (AUM) in building the civilization of Islamic economy.

Keywords: Ijtihad, Tajdid, Islamic Business, Islamic Economy.

\section{Abstrak}

Mubammadiyah menegaskan bahwa pintu ijtihad dan tajdid selalu terbuka dan tidak pernah tertutup. Ijtihad merupakan elemen yang penting yang menjadi karakter dasar Muhammadiyah sebagai gerakan modern Islam pembaharuan. Dasar tajdid (pembaruan Islam) kemudian berkembang menjadi upaya untuk memperbaiki sistem gerakan Mubamadiyah dalam mencari solusi bagi permasalahan ideologi, politik, ekonomi, sosial, budaya, pertahanan, keamanan, dan lainnya. Mubammadiyah yang pada awalnya bergerak sebagai gerakan sosial keagamaan terus melakukan upaya komprehensif untuk memberikan andil besar bagi kemajuan masyarakat Islam, khususnya di Indonesia. Sejalan dengan ijtihad dan tajdid, pemikiran Mubammadiyah sebagai gerakan sosial keagamaan menancapkan akar geraknya pada ruang ekonomi. Majelis Ekonomi dan Kewirausahaan (MEK) Muhammadiyah memiliki fokus agenda pada pengembangan Amal Usaha Mubammadiyah (AUM). Dawam Rahardjo (2000) mengungkapkan, anggota yang besar dan lembaga yang banyak. jumlabnya dapat dipandang sebagai modal atau sumber daya yang merupakan comparative advantage bagi pergerakan Muhammadiyah. 
Sumber daya itu telah mendorong gerakan Mubammadiyah tidak saja merupakan gerakan sosial-pendidikan-keagamaan, tetapi juga sebagai gerakan ekonomi dan bisnis. Setidaknya ada dua hal yang menjadi alasan Mubammadiyah mengembangkan usaba perekonomian. Pertama, bahwa Mubammadiyah punya keyakinan untuk tetap menggarap amal usaha bidang bisnis ini karena amal usaha ini tidak kalah strategisnya dibandingkean amal usaba-amal usaha Mubammadiyah yang lain, baike pendidikan, rumah sakit, maupun dakwah keagamaan. Kedua, bahwa Mubammadiyah punya potensi besar menggarap amal usaha ini. Dengan fakta banyaknya birokrat yang duduk di Pimpinan Mubammadiyah, banyaknya sumber daya manusia hasil pendidikan Mubammadiyah, banyaknya pengusaha-pengusaba besar di kalangan Mubammadiyah, banyaknya jumlah anggota Mubammadiyah. Artikel ini membahas penelitian tentang Mubammadiyah-Nomic, kontribusi ijtihad dan tajdid Amal Usaba Mubammadiyah (AUM) dalam membangun peradaban ekonomi Islam.

Kata Kunci: Ijtihad, Tajdid, Bisnis Islam, Ekonomi Islam.

\section{A. Introduction}

Muhammadiyah is as social-religion organization in Indonesia was found in November 18, 1912 through the spirit of islamic modernization. The involvement of those islamic organizations such as Muhammadiyah and Nahdhatul Ulama in looking after the pattern of islamic moderate in Indonesia has been giving the significant contribution in the process of democratization. ${ }^{1}$

Dengan sedikit bitjara banjak bekerdja, Muhammadijah telah memodernisasi tjara mengembangkan Islam, sehingga di selurub tanah air Indonesia, mulai Sabang sampai Meranke telah berdiri tjabang-tjabang dan ranting-rantingnja. Selaku seorang jang pernah berketjimpung dalam lingkungan Mubammadijah, saja ingin berpesan kepada saudara-saudara, supaja selalu berpegang tegub kepada motto:

${ }^{1}$ A.L. Freedman, "Civil Society: Moderate Islam and Politics in Indonesia and Malaysia”, Journal of Civil Society, Vol. 5, No. 2, 2009, p. 107-127. 
"banjak bekerdja"! Inilah sebabnja: Muhammadijab berkumandang dan menjadi besar. ${ }^{2}$

Muhammadiyah determines that the gate of ijtihad always opens and it is never closed. Ittiba' and ijtihad are such two important elements that become fundamentall chacarter of Muhammadiyah is being tajdid movement. ${ }^{3}$ At first, Muhammadiyah is such a social movement which keeps doing comprehensive efforts to give the big contribution for the moslem society particularly indonesian. Mitsuo Nakamura says that, since its establishment the Muhammadiyah has positive contributionm, the most prominent is as the movement of civil society. First, Muhammadiyah created the unity and lodge of nations through building and developing the existence of the Republic of Indonesia since its establishment. Second, Muhammadiyah is the container that was instrumental in developing the initiative citizens independently. ${ }^{4}$

In the line of ijtihad and tajdid, Muhammadiyah as a religious social movements gained root movements on the space economy. The Assembly's Economic and Entrepreneurship (MEK) Muhammadiyah has focused the agenda on the development of Charity Efforts Muhammadiyah (AUM). Dawam Rahardjo offers, a member of the large institutions which has much amount can be considered as capital or resources that constitute the comparative advantage to the movement of Muhammadiyah. The resources have pushed the movement of Muhammadiyah, thosemovements

${ }^{2}$ Faozan Amar (ed.), Soekarno dan Mubammadiyah (Jakarta: al-Wasath Publishing House, 2009), p. 51.

${ }^{3}$ Pradana Boy ZTF, Para Pembela Islam: Pertarungan Konservatif dan Progresif di Tubuh Muhammadiyah (Depok: Gramata Publishing, 2009), p. 65.

${ }^{4}$ Interviews were conducted Haedar Nasir in 1988. In the Steering Committee for al-Islam and Kemuhammadiyahan, Mubammadiyah History, Thought, and Amal Enterprises (Yogyakarta: Tiara Discourse, 1990), p. 113-115. 
are not only such a social-educational-religious, but also as economic and business movement. ${ }^{5}$

Moreover, the goals of Muhammadiyah in building "The Grand Communities", it seems indispensable to economic development. ${ }^{6}$ K.H. A.R. Fachrudin in business dialogue of Muhammadiyah on 17 December 1990 gave the message with the title "Muslims should not leave the matter of the economy". 7 At least, there are two things that become the reason of Muhammadiyah in developing the economy. First, Muhammadiyah has the confidence to keep working on this field of business of charity, since the charity effort is no less than its charitable efforts of Muhammadiyah such as education, hospitals as well as da'wah. Second, the execution of the enormous potential of Muhammadiyah had a charity venture. With facts: (1) large number of bureaucrats sitting in the leader of Muhmmadiyah; (2) the large number of human resources education results of Muhammadiyah need not doubt; (3) the large number of entrepreneurs among the large Muhammadiyah; (4) the number of members of the Muhammadiyah.

Reffering to the some cases above, Muhammadiyah also has vision of social welfare charity, that is "building people who embody the ideals of the ukhuwwah (fraternity), burriyyah (freedom), musawah (equation), and 'adalah (justice)". ${ }^{8}$

${ }^{5}$ Edy Suandi Hamid, M. Dasron Hamid, and Sjafri Sairin (ed.), Rekonstruksi Gerakan Mubammadiyah pada Era Multiperadaban (Yogyakarta: UII Press, 2000), p. 147.

${ }^{6}$ M. Dawam Rahardjo, "Dimensi Ekonomi dalam Masyarakat Utama”, M. Yunan Yusuf (ed.), Masyarakat Utama: Konsepsi dan Strategis (Jakarta: Perkasa with PP Muhammadiyah, 1995), p. 120.

${ }^{7}$ Lukman Soegito, "Revitalisasi Amal Usaha Muhammadiyah (Amal Usaha Ekonomi)", archive Seminar and Workshop Toward Muhammadiyah 44 $4^{\text {th }}$ Congress, "Rekonstruksi Gerakan Muhammadiyah", Universitas Muhammadiyah Malang, 27-28 Mei 2008, p. 2.

${ }^{8}$ Chusnan Jusuf, "Revitalisasi Amal Usaha Muhammadiyah di Bidang Kesejahteraan Sosial", archive Seminar and Workshop Toward Mubammadiyah 44 Congress, "Rekonstruksi Gerakan Muhammadiyah", Universitas Muhammadiyah Malang, 27-28 Mei 2008, p. 9. 


\section{B. Discussion}

\section{Tarjih of Islamic Economy in Muhammadiyah ${ }^{9}$}

Muhammadiyah in carrying out the process of ijtihad and related tajdid Islamic economics as follows:

a. Decision Legal Affairs Committee on "The Book of Some Problems" No. 19 a and b;

b. The decision of the Legal Affairs Committee in Sidoarjo in 1968 on the subject of the bank, particularly the number 4 that suggest to PP Muhammadiyah to seek the realization of the conception of the economic system, especially the banking institutions in accordance with Islamic qaida';

c. The decision Wiradesa Legal Affairs in 1972 on Banking no. 1 mandated the PP Muhammadiyah to soon be able to meet Congress's decision in Sidoarjo 1968 Legal Affairs on the realization of the conception of the economic system, especially the banking institutions in accordance with Islamic qaida';

d. Decision Tarjih in Malang in 1989;

e. Decision Tarjih in 2003.

\section{Economy Tajdidin Muhammadiyah}

Then the Legal Affairs Committee and the Central Executive Tajdid Muhammadiyah decided fatwa: ${ }^{10}$

a. Islamic Economics is an economic system based on sharia values which include fairness, honesty, interest-free, and is committed to improve the common welfare;

b. For the enforcement of Islamic economics, Islamic missionary movement Muhammadiyah as enjoining

${ }^{9}$ Majelis Tarjih dan Tablig PP Muhammadiyah, Kumpulan Keputusan Tarjih.

${ }^{10}$ The Result, "Rakernas and Business Gathering", MEK PP Muhammadiyah, 19-21 Agustus 2006, p. 30. 
good and forbidding wrong and tajdid, need to be actively involved in developing and advocating Islamic economy within the framework of the public welfare;

c. Interest is riba because: (1) it is in addition upon the principal capital lent, when God said, "And if you repent (of taking usury), then before you staple your treasure"; (2) additional binding and exchanged whereas that is voluntarily and not enforced by not including the riba;

d. Economic Sharia asked to increase the income such as Sharia principles;

e. Encouraging the whole range and Muhammadiyah and Muslims in general to be accordance with Islamic principles, and if get into trouble can be guided by the rule "One thing when experiencing difficulties and hardships brought by the spaciousness of convenience";

f. Muslims in General and the citizens of Muhammadiyah in particular in order to increase the appreciation of sharia principles-based on economic and the culture to develop the economy based on Islamic values;

g. In order for this fatwa disseminated to their understandable;

h. Conveyed in Yogyakarta June 27, 2006. ${ }^{11}$

\section{The Contribution of Ijtihad and Tajdid toward AUM in Building the Civilization of Islamic Economy}

In the beginning, Muhammadiyah was mostly driven by merchants of batik in Yogyakarta, it looks at the early period of the founding of the Muhammadiyah members composition is dominated by those who had behind it

\footnotetext{
${ }^{11}$ Fatwa Majelis Tarjih dan Tabligh PP Muhammadiyah, Yogyakarta, 27 Juni 2006.
} 
the merchants (Syafrudin Anhar). The membership data in 1916, listed as the following: merchants $47,0 \%$ selfemployed, employees/official 18,1\%, 12,1\%, private scholars $10,7 \%, 8,7 \%$, labour journalist and $0,7 \%$. At that time, the development of the Muhammadiyah developed due to the interaction of batik traders have a plot, then proponents of Muhammadiyah do Da'wah and relation as in Pekalongan, Pekajangan, Solo, Kotagede (Yogyakarta), Minangkabau, and recently it was developed in the area of entrepreneurship (merchants) of Muhammadiyah is not a little. ${ }^{12}$

Muhammadiyah relation with economic activity provides some notes that: First, Muhammadiyah realizes the importance of unity of self-reliance because it is not part of the state while avoiding dependence on the efforts of others. Second, economic activity sufficient internal dynamicly enough among Muhammadiyah shows that Muhammadiyah is still dominated by the urban middle class that is relatively stable in economic activity. Thirdly, some economic activities, such as banks, treasury, actually since the beginning has been initiated and the agenda in economics Muhammadiyah, but not enough to be a record. This important to continue to evaluate and seek new models of articulation of Muhammadiyah in the economic field. ${ }^{13}$

In an interview with Dr. Abdul Mu'ti, M.Ed., the secretary of Muhammadiyah stated that, "Muhammadiyah is clearly going to continue to deal with the state. If there are organizations that do not intersect with the government as possible during the preaching only to invite people to pray alone. But we know that Muhammadiyah has Hospitals,

${ }^{12}$ Syafrudin Anhar, "Revitalisasi Gerakan Ekonomi di Muhammadiyah", Paper Seminar Pra Muktamar in UAD Yogyakarta, 2010.

${ }^{13}$ Majelis Diktilitbang and LPI PP Muhammadiyah, 1 Abad Muhammadiyab: Gagasan Pembaharuan Sosial Keagamaan (Jakara: Kompas, 2010), p. 242. 
educational institutions, charitable efforts of others so that it will always intersect." 14

Muhammadiyah established a large number of schools, teacher education and has publications and activities related to social welfare. Muhammadiyah schools have helped educating Indonesian nationalists, and its activities against the development of communism and radical secularism. Muhammadiyah continues to serve actively associations in the field of education and socio-cultural whole the era in cathcing the independence. ${ }^{15}$

Besides, Abdul Mu'ti also said, "We bought the land and buildings in Cairo Egypt to be a branch of Muhammadiyah. It is not for showing, but this is our expansion into the International. Now the Sharing Economy era, no longer own economy, this Muhammadiyah's Charity Effort to unify, then it doesn not enrich themselves. We have proved unable to fund the construction of the hospital with money from BMT worth 26 billions. We will build the Muhammadiyah University International, the tallest building in Jakarta. So if Mr. Haidar want to go to the nearest helicopter. We must jump and in the end it's a matter of time. The university of Muhammadiyah Metro is great and we should be aware of all the potential for greatness. So Muhammadiyah future must have a big dream. We must do is we must have the greatness together, not just the individual greatness."

According to Dawam Rahardjo, there are three reasons that make the Muhammadiyah to involve themselves directly in the thought and movement of people empowerement. First, the symptoms of the economic downturn people are

${ }^{14}$ Interview with Abdul Mu’ti, Sekretraris PP Muhammadiyah, 2 April 2016, suave activities prior to the appointment of Trustees PDM Metro City in Muhammadiyah University of Metro.

${ }^{15}$ Haedar Nashir, Dinamika Politike Muhammadiyah (Malang: UMM Press, 2006), p. 105. 
generally engaged in small industry and handicraft as a result of industrialization and development policies of the new order that is causing the marginalization of small businesses. Secondly, the influence gait non-governmental organizations (NGOs) which, among other activities fostering of small and informal sector. Third, the birth of Muhammadiyah generation of professionals in the environment thanks to advances in education, which are active in NGOs or bureaucrats involved in the development program. ${ }^{16}$

Muhammadiyah has seriously in strengthening the local economy also began to involve entrepreneurs nonnative (China). Lukman Harun (Deputy Chairman of PP Muhammadiyah), in a discussion on May 13, 1990 at Hotel Sahid Jakarta, stated that Muhammadiyah needs to learn a lot of Chinese friends who were in Indonesia. According to Lukman Harun, assimilation is not an issue for Muhammadiyah. ${ }^{17}$

The results of interviews with Safrudin Anhar ${ }^{18}$ as Chairman of Council of Economics and Entrepreneurship (MEK) PP Muhammadiyah in Jakarta from 2010 to 2015. Safrudin Anhar said, "In this period, especially MEK Muhammadiyah Central Executive consolidate below the structure in order to increase charitable efforts of Muhammadiyah in a form of economic movement."

Safrudin added that there are three potential economic Muhammadiyah. First, the number of cadres of

${ }^{16}$ M. Dawam Rahardjo, "Pengembangan Perekonomian Masyarakat: Sebuah Alternatif Model bagi Muhammadiyah", in M.A. Fattah Santosa and Maryadi (ed.), Mubammadiyah Pemberdayaan Umat? (Surakata: Muhammadiyah University Press, 2000) p. 109.

${ }^{17}$ Sazali, Muhammadiyah dan Masyarakat Madani: Independensi, Rasionalitas, dan Pluralisme (Jakarta: PSAP Muhammadiyah, 2005), p. 164.

${ }^{18}$ Interwiew with Safrudin Anhar, Chairman of Council of Economics and Entrepreneurship (MEK) PP Muhammadiyah 2010-2015, March 19, 2012 in Muhammadiyah Building Jakarta. 
Muhammadiyah. Secondly, the resources of the charity efforts of Muhammadiyah. Third, network of Muhammadiyah. The sstablishment of MEK is the result of the process of ijtihad and tajdid economic thinking which leads to empowerment of AUM which focus more on the economic movement of Islam. The strategic role of MEK is how recently it was able to unearth and harness the economic potential that exists in Muhammadiyah.

The process of ijtihad and tajdid always will be continued by Muhammadiyah and will not stop here, so that efforts to improve the professionalism of the economic movement. Muhammadiyah has started to build the movement is no longer charitable social enterprises by establishing charitable religious but economic enterprises. And educational institutions should be resources to build human understanding of Islamic economics.

So it is very clear that ijtihad and tajdid in Muhammadiyah is very influential in the development of Islamic Economics characterized by AUM. In Decision 1968 Tarjih Sidoarjo decided that:

a. Riba is haram, with nash sharih Qur'an and Sunnah;

b. Bank with usury system is haram and banks without usury lawfull;

c. The interest granted by the state-owned bank to its customers or vice versa so far applicable, including the case mutashabihat;

Suggest to the PP Muhammadiyah to seek the realization of the conception of the economic system in particular banking institution according to the rules of Islam. ${ }^{19}$

${ }^{19}$ Quoted in the writings of Soertina Nitisoemantri, "Muhammadiyah and the Development of Contemporary Mu'amalah", delivered at a National Seminar on the Development of Islamic Thought between Purification and Dynamics, LPPI Muhammadiyah University of Yogyakarta, June 22-23, 1996, p. 7. 
The working meeting of Muhammadiyah Economic Assembly II in 1989 in Ciawi, ${ }^{20}$ decided in the fields of banking, among others, continue the program of formation of BPR, with target in 1990 formed fruit 100 BPR, and every wiliyah there is a minimum of $1 \mathrm{RB}$. Its realization of combined teams of economic Assembly of PP Muhammadiyah on January 14, 1990 at the Hotel Sari Pacific Jakarta, ${ }^{21}$ decided among other things:

a. Approve the establishment of the Foundation or Institution (Legal) Banking and Financial Development;

b. BPR (conventional) Ciputat named PT BPR Sun Arthadaya is a pilot project. ${ }^{22}$

Interview with Muhammad Ridwan, SE, M.Ag., Economic Council Chairman and Entrepreneurship Regional Chairman of Muhammadiyah (PWM) Special Region of Yogyakarta (DIY), ${ }^{23}$ ijtihad in Muhammadiyah more praxis in the field of economics that Muhammadiyah is the leading sector in terms of economic development. Tajdid after one century of Muhammadiyah in the movement to 4 after the education, health, and the orphanage is the economy.

Tajdid Muhammadiyah economic is how Muhammadiyah does economic empowerment for the poor. The impact of ijtihad and tajdid Muhammadiyah in very influential economic and charitable efforts in each area. There are influences that occur in the process of ijtihad and tajdid Muhammadiyah in the development of the charity

${ }^{20}$ Ibid., p. $7-8$.

${ }^{21}$ Ibid., p. 8.

${ }^{22}$ After the birth of the banking Act No. 7/92 and PP. No. 72/92 regarding the system for bank results, BPR Arthadaya Sun has not changed the status of Ciputat conventional to Sharia.

${ }^{23}$ Interview with Muhammad Ridwan, Economic Council Chairman and Entrepreneurship Regional Chairman of Muhammadiyah (PWM) Special Region of Yogyakarta, June 3, 2015. 
efforts of Muhammadiyah. Where Muhammadiyah plays the role of policies and the role of running the business. As my proposal the center and the region's base area and branch policies and your effort in the field.

Islamic cooperative must give space to the poor individual to have a specific subject matter or deposits in Act No. 17 of 2012 set the States Capital of Cooperatives (CMS). It is important that the little people have a stake no matter how small it is. Cooperative sharia as BTM and BMT Muhammadiyah, this responds to lift the little people the same rights to work together to build capital. Not long ago Muhammadiyah Yogyakarta build independent Dai, Charter Schools, and Orphanages Mandiri. Economics and Entrepreneurship Council (MEK) Muhammadiyah Yogyakarta has started to build the organization and board independence.

Specifically, Yogyakarta Muhammadiyah Executive Board continues to seek to build up the spirit in which the renewal movement Muhammadiyah is mandatory to answer the challenges of the times. The right momentum and this century to make the post-war movement Muhammadiyah started to rethink economic independence has ever been successful in the K.H. Ahmad Dahlan.

Interview with Iwa Khairuttaqwa, S.Th.I. as the Manager of the BTM Umbulharjo, Yogyakarta. ${ }^{24}$ According to Iwa, the process of ijtihad and tajdid economy in Muhammadiyah is a response of the Da'wah of Islam teaches that in Muhammadiyah not only tablig assemblies but also about economic teachings of Islam which has a clearer concept.

${ }^{24}$ Interview with Iwa Khairuttaqwa, as the Manager of the BTM Umbulharjo, Yogyakarta, May 1, 2015. 
One of the tajdids in the economy in Muhammadiyah is by establishing BTM and PP Muhammadiyah decision very clearly how each PCM stands one BTM or BMT Muhammadiyah. Iwa added that ijtihad and tajdid very influential because Muhammadiyah is a large organization that structured so that when there is a decision of the centre on the lower level sami'na wa ata'na (we hear and we obey).

Muhammadiyah with the national network will be easy to give effect in the form of policies such as the establishment of BTM and BMT Muhammadiyah. The role of the Economic Council and Entrepreneurship is important to build strategic steps in which the grassroots level (grassroots) easy to run more programs simultaneously economy.

The level of Muhammadiyah's administrators understanding about the Islamic economic have been growing well and need to be upgraded to the citizens of Muhammadiyah. Muhammadiyah is very important to master the economy. K.H. Ahmad Dahlan teaches us all how to pay attention to the social side with he initiated building up education and health. So that is how the Da'wah tajdid economy needs to continue to be built as concrete evidence that Islam is a religion that kaffah (comprehensive). If Muhammadiyah does not call in economic means Da'wah Muhammadiyah incomplete yet thorough (syumū).

The authors further interview with H. Zamawie, A.Md, ${ }^{25}$ as Chairman of the Board BTM kotagede. H. Zamawie, A.Md. revealed, the initial intention was to help establish BTM economic improvement of the lower classes. It also gives space Muhammadiyah traders in the town's excited by the Islamic financial institutions.

${ }^{25}$ Interview with Zamawie, as Chairman of the Board BTM Kotagede, April $31,2015$. 
During this time the board is difficult given the understanding BTM is the parents, young cadre of Muhammadiyah in contrast to the more progressive capture SME development opportunities in the town. We are inspired by Muhammadiyah East Java, where the development of financial institutions they were incredible. BTM and BMT where they develop huge with hundreds of billions of assets.

BTM Kotagede is different from BMT ever established Muhammadiyah. Due to this decision in accordance with the BTM-led Centre of Muhammadiyah. Although the community more memorized by BMT however BTM remains a hallmark of Muhammadiyah. And in some places belief that financial institutions have built a BMT earlier gradually has changed its name to BTM.

I feel we need to think of regeneration in the future how recently it was able to provide training to the younger generation. But still ijtihad and tajdid PP Muhammadiyah through MEK very influential towards the expansion of Charitable Efforts appear and Muhammadiyah including financial institutions established Muhammadiyah.

Interview with Drs. Muhammad Ansari, Chairman of the Board of BMT an-Ni'mah in the town. Understanding the economic ijtihad is Muhammadiyah seeks new solutions to the economic problems of the people. While tajdid economic perspective, namely actualization movement Muhammadiyah Muhammadiyah economy. One example, Muhammadiyah perform work related economic empowerment community group Muhammadiyah. Ijtihad and tajdid affect the development of the charitable efforts of Muhammadiyah in particular the development of BMT anNi'mah. Muhammadiyah organization moves automatically to follow the decision of Muhammadiyah. Obviously this is 
very influential on the development of Muhammadiyah in the area. Although I saw a severed communications between the central and local Muhammadiyah dualism associated with BTM and BMT in Muhammadiyah.

Muhammadiyah builds its business charity aims to build and strengthen the economic cadre Da'wah economic Muhammadiyah. Charitable efforts in education and health for example all cadres of Muhammadiyah co-owns stock build charity business. Likewise in BMT Muhammadiyah, Muhammadiyah cadres are expected to participate in ownership. BMT an-Ni'mah also give results for Da'wah Muhammadiyah for example we give results to the Muhammadiyah branch amounted to 18 million per month. Interview with Uwang Wari, $\mathrm{SE}^{26}$ as Manager of BMT UMY. The citizens of Muhammadiyah established BMT and BTM is the recommendations of the congress. But the Muhammadiyah Center haven't done an intensive coaching against the construction of the BMT and BTM in every area. The hope fore PP Muhammadiyah should be able to reach to the root.

Ijtihad and tajdid remained influential on the development of BMT and BTM although limited in the implementation of PP Muhammadiyah movement to reach all areas of Muhammadiyah in Indonesia. Muhammadiyah has many amal effort must be managed for the benefit together. BMT UMY elected by citizens on grounds of Muhammadiyah in UMY follow only when the market brandname basis BMT took BTM UMY not that which has been established by the organization Muhammadiyah. It is my understanding that the BMT UMY built on ijtihad and tajdid at the University of Muhammadiyah Yogyakarta (UMY). Muhammadiyah community response to the establishment

\footnotetext{
${ }^{26}$ Interview with Uwang Wari as Manager of BMT UMY, May 5, 2015.
} 
of BMT has been very good. Muhammadiyah members who build structures BMT outside Muhammadiyah is also a lot like BMT Binangun in Godean.

Ijtihad and tajdid Muhammadiyah always based from the Qur'an and the Sunnah. But in terms of the implementation is not necessarily relevant to practice. As an example in terms of opinion of the covenants, and riba which Muhammadiyah in agreement. However during these campuses do not run in accordance with Muhammadiyah fatwa haram the riba. Examples of Muhammadiyah University of Yogyakarta (UMY) and Ahmad Dahlan University (UAD) are teaming up with conventional banks. This makes the Muhammadiyah in charity business education is not consistently running the covenants, and usury. It is also possible this is due to their historical relationship that has long partnership.

Interview with Hadi Supono, ${ }^{27}$ Chairman of the Executive Board and BTM Assembly Economic and entrepreneurial PCM Limestone and Vice Chairman of the PDM MEK Sleman. The charitable efforts of Muhammadiyah PDM and PCM Limestone managed with various efforts. The citizens of Muhammadiyah Limestone in Sleman is very focused raising AUM Limestone.

Ijtihad economy is everything that is done by Muhammadiyah in order to provide benefits to the people. In the form of economic ijtihad establish economic enterprises to develop economic life at Muhammadiyah propaganda. In this Sleman PDM BTM establishs Limestone which has assets of 1,3 billion, Stores Building, Limestone Hospital, the Institute of Education, and others.

Muhammadiyah develops economy to really present in the community give the solution and peace together. With

${ }^{27}$ Interview with Hadi Supono, Chairman of the Executive Board and the Chairman of Gamping, June 2, 2015. 
this economic PDM Sleman AUM could give scholarships from kindergarten to college. Giving aid to the poor, and do community economic empowerment.

Edy Suandi Hamid revealed several factors that strongly supported internally to build a business network and the economic power of Muhammadiyah. First, the presence of citizens and sympathizer of Muhammadiyah. Second, the Muhammadiyah has network organization from central level to twigs. Third, the existence of institutions of Muhammadiyah which spread in various corners of the ground water. Fourth, Muhammadiyah with various social activitiy is already known by the public at large. Fifth, most citizens of Muhammadiyah has been known as a businessman or a tough business. ${ }^{28}$

Table 1. The Data of Muhammadiyah Charitable Enterprises

\begin{tabular}{clc}
\hline No. & Sorts of Enterprises & Amount \\
\hline 1 & TK/TPQ & 4.623 \\
\hline 2 & Elementary School & 2.604 \\
\hline 3 & Junior High School & 1.772 \\
\hline 4 & Senior High School & 1.143 \\
\hline 5 & Boarding School & 67 \\
\hline 6 & The number of Muhammadiyah Universities & 172 \\
\hline 7 & Hospitals, Maternity Hospital, BKIA, BP, etc. & 457 \\
\hline 8 & Charities, orphanages, Foster Families, etc. & 318 \\
\hline 9 & Panti jompo & 54 \\
\hline 10 & Nursing homes & 82 \\
\hline
\end{tabular}

${ }^{28}$ Masykur Wiratmo and Edy Suandi Hamid, "Membangun Perekonomian Warga Persyarikatan di Tengah Krisis Ekonomi”, Edy Suandi Hamid, M. Dasron Hamid, and Sjafri Sairin (ed.), Rekonstruksi Gerakan Muhammadiyah pada Era Multiperadaban (Yogyakarta: UII Press, 2000), p. 159. 


\begin{tabular}{llc}
\hline 11 & Rehabilitation of Disabled School (SLB) & 71 \\
\hline 12 & Mosque & 6.118 \\
\hline 13 & Musholla & 5.080 \\
\hline 14 & Land & $20.945 .504 \mathrm{~m}^{2}$ \\
\hline 15 & BTM/BMT & 263 \\
\hline 16 & KSU Syariah & 344 \\
\hline 17 & BPRS & 19 \\
\hline
\end{tabular}

Source: Amal Usaha Muhammadiyah, 2015, www.muhammadiyah. or.id.

\section{Conclusion}

From the research that the author do to be drawn the conclusion that the existence of a positive influence between ijtihad and the charitable Efforts of Muhammadiyah Tajdid (AUM) in economic development Islam Berkemajuan especially BTM and BMT in Yogyakarta.

These influence can be seen from the decision of Congress, Fatwa Legal Affairs Committee, Economic and Entrepreneurship Council decisions, and meetings such as Rakernas National, Workshops, Workshop, Seminar, and the Tanwir Muhammadiyah Convention related to the development Muhammadiyah Charitable Enterprises. Ijtihad and tajdid Muhammadiyah gave a firm line on the attitude and Enterpreneurship Economic Council (MEK) to give the national decision at board level Regional and Branch Muhammadiyah. The decision to be a platform of economic movement Muhammadiyah in particular the development of Islamic economics at the macro and micro levels. Amal Development Efforts of Muhammadiyah (AUM) consist of various agencies Business Charity charitable efforts 
include education, health, including in the field of social and religious like.

Educational institutions from early childhood to university, hospital, foundation orphans, and in the economy such as financial institutions SRB, BMT, supermarket, and other diverse in every area. In a special study Amal Economic Enterprises, the author examines the BTM and BMT in Muhammadiyah, the development of microfinance institutions continue to increase the amount of time. 


\section{REFERENCES}

Abdurrahman, Asjmuni. Manhaj Tarjïh Mubammadiyab: Metodologi dan Aplikasi. Yogyakarta: Pustaka Pelajar, 2007.

Alfian. Muhammadiyab: the Political Behavior of a Modernist Organization under Dutch Colonialism. Yogyakarta: Gadjah Mada university Press, 1989.

Amar, Faozan (ed.). Soekarno dan Muhammadiyah. Jakarta: alWasath Publishing House, 2009.

Boy ZTF, Pradana. Para Pembela Islam: Pertarungan Konservatif dan Progresif di Tubuh Mubammadiyah. Depok: Gramata Publishing, 2009.

Djamil, Fathurrahman. Metode Ijtihad Majlis Tarjih Muhammadiyah. Jakarta: Logos, 1995.

Federspiel, Howard M. "The Muhammadiyah: a Study of an Orthodox Islamic Movement in Indonesia”, Indonesia, October 10, 1970.

Freedman, A.L. "Civil Society, Moderate Islam, and Politics in Indonesia and Malaysia", Journal of Civil Society, Vol. 5, No. 2, 2009.

Fuad, Ahmad Nur. Pengaruh Kontinuitas dan Diskontinuitas Pemikiran Keagamaan dalam Mubammadiyah (1923-2008) Tinjauan Sejarah Intelektual. Surabaya: IAIN Sunan Ampel, 2010.

Hamid, Edy Suandi, M. Dasron Hamid, dan Sjafri Sairin (ed.). Rekonstruksi Gerakan Muhammadiyah pada Era Multiperadaban. Yogyakarta: UII Press, 2000.

Hasan, Ahmad. Sebelum Pintu Ijtihad Tertutup. Bandung: Penerbit Pustaka, 1970. 
Iqbal, Sir Muhammad. The Recontruction of Religions Thought in Islam. Lahore: S.H. Muhammad Ashraf, 1986.

Majelis Diktilitbang and LPI PP Muhammadiyah. 1 Abad Muhammadiyah: Gagasan Pembaharuan Sosial Keagamaan. Jakara: Kompas, 2010.

Nakamura, Mitsuo. Bulan Sabit Muncul dari Balik Pohon Beringin: Studi Tentang Pergerakan Mubammadiyah di Kotagede Yogyakarta. Yogyakarta: Gadjah Mada University Press, 1983.

Nashir, Haedar. Dinamika Politik Muhammadiyah. Malang: UMM Press, 2006.

Nashir, Hedar. Muhammdiyah Abad Kedua. Yogyakarta: Suara Muhammadiyah, 2011.

Noer, Deliar. Gerakan Modern Islam di Indonesia 1900-1942. Jakarta: LP3ES, 1980.

Peacock, James L. Muslim Puritans: Reformist Psychology in Southeast Asian Islam. Berkeley: University of California Press, 1978.

Peacock, James L. Purifying the Faith: the Mubammadiyah Movement in Indonesian Islam. California: the Benjamin Cummings Publishing Company, 1978.

Rahardjo, M. Dawam. "Pengembangan Perekonomian Masyarakat: Sebuah Alternatif Model bagi Muhammadiyah", M.A. Fattah Santosa and Maryadi (ed.). Muhammadiyah Pemberdayaan Umat? Surakata: Muhammadiyah University Press, 2000.

Rahardjo, M. Dawam. "Dimensi Ekonomi dalam Masyarakat Utama", M. Yunan Yusuf (ed.). Masyarakat Utama: Konsepsi dan Strategis. Jakarta: Perkasa with PP Muhammadiyah, 1995. 
Sazali. Mubammadiyah dan Masyarakat Madani: Independensi, Rasionalitas, dan Pluralisme. Jakarta: PSAP Muhammadiyah, 2005.

Soegito, Lukman. "Revitalisasi Amal Usaha Muhammadiyah (Amal Usaha Ekonomi)", Seminar dan Sarasehan Muhammadiyah Menyongsong Muktamar Ke-44, Rekonstruksi Gerakan Muhammadiyah, Universitas Muhammadiyah Malang, May 27-28, 2008.

Sudjarwanto, Haedar Nashir, and M. Rusli Karim (ed.). Muhammadiyah dan Tantangan Masa Depan: Dialog Intelektual. Yogyakarta: Tiara Wacana, 1990.

Syamsuddin, Din. "Religion and Politics in Islam: the Case of Muhammadiyah in Indonesia's New Order", Dissertation, University of California Los Angeles, 1991.

Wiratmo, Masykur and Edy Suandi Hamid. "Membangun Perekonomian Warga Persyarikatan di Tengah Krisis Ekonomi", Edy Suandi Hamid, M. Dasron Hamid, and Sjafri Sairin (ed.). Rekonstruksi Gerakan Mubammadiyah pada Era Multiperadaban. Yogyakarta: UII Press, 2000. 
Dharma Setyawan

Halaman Ini Tidak Sengaja Untuk Dikosongkan. 